\title{
APPLICATION OF IN -VESSEL COMPOSTING WITH FORCED AERATION FOR BIODEGRADABLE SOLID WASTE USING SAW DUST AS BULKING AGENT
}

\author{
Kanchanabhan T. E. , Syed Sha M. ${ }^{2}$, Helensanthi M. ${ }^{3}$, Abbas Mohaideen J. ${ }^{4}$ Ravindran B. ${ }^{5}$, Sekaran G. ${ }^{5}$ \\ ${ }^{1}$ Research Scholar, Department of Civil Engineering, Sathayabama University, Chennai, India \\ ${ }^{2,3}$ Department of Civil Engineering, Sathayabama University, Chennai, India \\ ${ }^{4}$ Maamallan Institute of Technology, Sriperumpudur, India., ${ }^{5}$ Central Leather Research Institute, Chennai, India \\ Email: ${ }^{1}$ tekanchan_77@rediffmail.com
}

\begin{abstract}
The process of composting had been studied using six different types of blends, each simulating different Carbon- Nitrogen $(\mathrm{C} / \mathrm{N})$ ratio for the formation of compost. The raw material was a mixture of bio degradable waste (University Mess), bulking agent (saw dust) and cow dung as compost accelerator Six composting bins each of $100 \mathrm{~L}$ capacity were installed with holes at various depth for probes and leachate collection system. The bins (length $50 \mathrm{~cm}$, width $40 \mathrm{~cm}$, height $50 \mathrm{~cm}$ ) were placed horizontally with a slight inclination to permit the collection of leachate. The evaluation studies included the operational indices such as temperature, $\mathrm{pH}$, moisture content, compost maturity indices like $\mathrm{C} / \mathrm{N}$ ratio, elements, bulk density and microbial survival. Blowers of this system were useful in maintaining aerobic condition (aeration at a rate of $2.3 \mathrm{~m} 3 / \mathrm{min}$ ) in the entire compost bay. Further germination studies were performed to ascertain the compost quality. The final compost having $\mathrm{C} / \mathrm{N}$ ratio around 20 was satisfactory for its agricultural application based on the results.
\end{abstract}

Key words: In-Vessel Composting, C/N ratio, Aeration, Moisture and Germination studies.

\section{INTRODUCTION}

The collection and disposal of solid waste had been rapidly becoming one of the major unsolved problems of urban areas in India (Srinath et al, 2006). Composting is defined as the controlled biological decomposition of organic substrates carried out by successive microbial population combining both mesophilic and thermophilic activities, leading to the production of a final product sufficiently stable for storage and application to land without adverse environmental effects. Two types of composting system had been widely applied: In-vessel systems and Window systems. The technology called in-vessel composting is a system that comprises a number of integrally related components including: material amendment, recycle, handling, storage, mixing, reactor system, odour-control system, aeration system, exterior curing with storage facilities and marketing of produced compost. This technology offer a highly controlled, enclosed environment for effecting the biological decomposition needed to produce a high quality product and tend to be considerably less capital intensive than windrow technologies. (Renkow et al, 1998). In- vessel composting has advantages over the window system: it would require less space and provide better control than windrows. It has high process efficiency (Chang et al, 2006). This study had been conducted to evaluate the performance of a lab-scale in-vessel composting and the evaluations were focused on operational indices such as compost maturity indices and the quality of the final compost. Forced-aeration had been recognized as simple, economical and quick treatment process for organic solid waste. It had also interested operators of other systems because of their low odor emission, which would result from their no-turning operation and an adequate air supply (Masafumi et al, 2002). The study also investigated changes in microbiological and physicochemical parameters during single batch composting of municipal organic waste. The inter-relationship between the microbial biomass as well as physicochemical parameters such as $\mathrm{pH}$, temperature and moisture Content were also evaluated. In recent years, the development and widespread use of more expensive in-vessel systems for the processing of green bio waste had been resulted from legislative pressures on the safety of the composting process and the subsequent use of the compost product. (Antilizar et al, 2004). Such systems also allow for more precise control particularly in terms of moisture and temperature. The scope of the study included the design and testing of a compost reactor working aerobically, which was inoculated with cow dung containing compost accelerating microorganisms and bulking agent such as saw dust to achieve substantial and rapid volume reduction of the bio waste. The compost from the designed aerobic reactor provides good humus to build up a poor physical soil and some basic plant nutrients. This proved to be an efficient, eco-friendly, cost-effective and nuisance-free solution for the management of solid waste. (Srinath et al, 2006).

\section{MATERIALS AND METHODS}

The process of composting were studied using six different types of reactors, each simulating a different condition for the formation of compost based on the $\mathrm{C} / \mathrm{N}$ ratio. Bio degradable solid waste from the University mess was mixed with cow-dung slurry. The cow dung was obtained from the cattle shed in Jeppaiar Milk. It was dried 
to remove odour and then $10 \%$ cow dung slurry was prepared as follows. $100 \mathrm{~g}$ of cow dung was mixed with $1000 \mathrm{ml}$ of water. The fibers in the water were filtered using cloth filter. Saw dust in a wood mill from the university was mixed with food waste in the rectangular bins. The saw dust had been sieved using $4.75 \mathrm{~mm}$ mesh and the particles retained in them were used as bulking agent supplemented with grains and minerals. Pilot tests were undertaken in a six 100-L bins. The reactor (length $50 \mathrm{~cm}$, width $40 \mathrm{~cm}$, height $50 \mathrm{~cm}$ ) was placed horizontally with a slight inclination to permit the collection of leachate. A plastic mesh was fitted at the bottom of the receptacle to support the material and separate it from possible leachate. A3-cm polyurethane foam layer provided thermal insulation. Several holes were perforated through the walls of the vessel to permit air movement, leachate removal and the insertion of different probes. adjust the $\mathrm{C} / \mathrm{N}$ ratio. Using the shovel, the mixture of food waste and bulking agent was moved twice a day for $30 \mathrm{~min}$. Forced aeration at a rate of $2.3 \mathrm{~m} 3 / \mathrm{min}$ was supplied to maintain adequate oxygen level and temperature inside the compost pile for a period of one hour per day at a rate of $2 \frac{1}{2}$ minutes per hour with timer system. In case of the compost samples and mature compost the compost was separated from bulking agents using $4.75 \mathrm{~mm}$ sieve. The compost samples at different decompositions degrees were dried at $600 \mathrm{C}$ for evaluation. It was ground in a coffee grinder to homogenize and powdered, dry samples (7-10 mg) were used for the analysis. The mixing ratio of bulking agent to food waste with cow dung had been described in Table 1 on a weight basis to adjust the $\mathrm{C} / \mathrm{N}$ ratio.

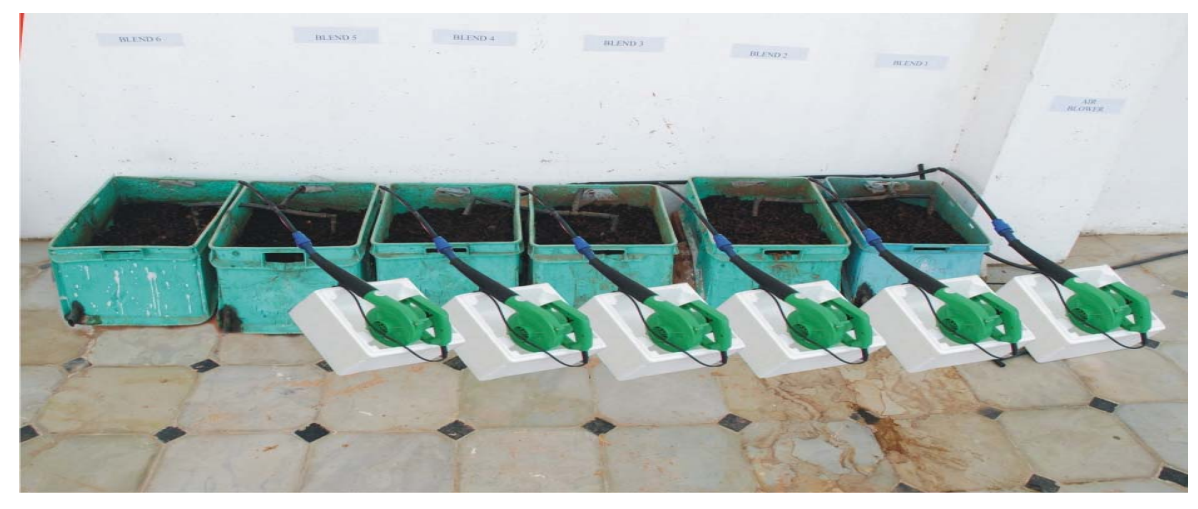

Fig. 1. View of Bins used in Composting

The loading of the reactor was performed by initially spreading a layer of pebbles of thickness $1 \mathrm{~cm}$ at the top of the under drainage perforated pipes. Then dry leaves were spread and sprinkled with water to impart some moisture within the bin. A layer of soil was placed over the leaves. The bins were then loaded with blends. A thin iron pipe with a uniform holed loop tail was kept inside the reactor for aeration and connected to blower. The iron pipe was connected to a stainless disc mesh placed at bottom. Aschematic diagram of the pilot-scale in-vessel composting plant evaluated in the study is illustrated in figure 1.
$1 \mathrm{~g}$ of dried sample each bin was taken. It was ground well and mixed with $50 \mathrm{ml}$ of water. (1:50 (w/v)). The $\mathrm{pH}$ was measured using a $\mathrm{pH}$ electrode. The moisture content (MC) was measured using hydrometer. The temperature was measured using multi stem thermometer. The analyzer Vario EL was used for the elemental analysis (carbon, nitrogen, hydrogen and sulphur) of the samples. Vandate Molybdate method and Flame photometer were used for the determination of phosphorous and potassium. Spectrometer following EPA $3050 \mathrm{~B}$.

Table 1. Typical composition of blends

\begin{tabular}{|c|c|c|c|c|c|c|}
\hline Material & Blend 1 & Blend 2 & Blend 3 & Blend 4 & Blend 5 & Blend 6 \\
\hline Cow Dung (g) & 500 & 500 & 500 & 500 & 500 & 500 \\
\hline Food waste (g) & 1250 & 2500 & 3750 & 5000 & 6250 & 7500 \\
\hline Saw dust (g) & 8250 & 7000 & 5750 & 4500 & 3250 & 2000 \\
\hline Total (g) & \multicolumn{7}{|c|}{10000} \\
\hline
\end{tabular}


Bulk density was determined using graduate cylinder method. Water Holding Capacity (WAC) values were determined by soaking the materials in distilled water for 24hours, draining off the gravitational water during another 24 hours under cover to limit evaporation and then drying at $103 \mathrm{OC}$ for $24 \mathrm{~h}$ to determine the final moisture content. Finally the germination study was done by growing seeds in compost obtained from different blends taken in plastic pots. Seeds were spread in layer of compost from different blends. A trace paper was placed in the top and sprinkled with water.

\section{RESULTS AND DISCUSSION}

The Central Public Health and Environment Engineering Organization (2000) specify that the nitrogen, phosphorous and potassium contents for compost should be more than $1 \%$ each. The nitrogen should be in the form of nitrates for proper utilization by the plants. The $\mathrm{C} / \mathrm{N}$ ratio should be between 15 and 20 . Hence the qualities of the composts produced in the different reactors were compared in the light of the above recommended properties.

\section{A. Variation of Carbon (\%)}

Carbon availability plays a major role in nitrogen immobilization. While degrading organic compounds, microbes utilize $60 \%$ to $70 \%$ of the carbon as carbon dioxide and immobilize only $30-40 \%$ of the carbon into their body as cellular components (Suzelle et al, 2003). Changes in the carbon content during the compost period for saw dust had been detailed in Table 2. The carbon content decreased gradually as the decomposition period progressed. Initially the contents were around $47 \%$. It had been drastically reduced in each blend to $34 \%$ to $18 \%$ respectively. Decomposition of organic matter is brought about by microorganisms that use the carbon as a source of energy and nitrogen for building cell structure. (Joung etal, 2007).

\section{B. Variation of Nitrogen (\%)}

Nitrogen content had increased in the blends in probably by mineralization of organic matter as well as loss of carbon (Polprasert et al, 1996). The increase of nitrogen showed the good quality of bio compost. Nitrogen fixing bacteria would also contribute the increase but in the blends 4, 5 and 6 the nitrogen content had decreased as shown in Table 3 . The stored nitrogen was then used by other organisms to form new cell material. In the process more carbon was used. Thus, the amount of carbon was reduced to a more suitable level while nitrogen is recycled.

Table 2. Variation of carbon in $\%$

\begin{tabular}{|l|c|c|c|c|c|}
\hline Days & $\mathbf{0}$ & $\mathbf{1 5}$ & $\mathbf{3 0}$ & $\mathbf{4 5}$ & $\mathbf{6 0}$ \\
\hline Blend 1 & 47.95 & 29.70 & 44.47 & 37.94 & 34.21 \\
\hline Blend 2 & 47.20 & 19.39 & 44.13 & 38.61 & 32.61 \\
\hline Blend 3 & 48.65 & 19.12 & 38.50 & 29.90 & 29.19 \\
\hline Blend 4 & 48.70 & 17.54 & 24.05 & 35.30 & 29.30 \\
\hline Blend 5 & 47.95 & 31.27 & 23.10 & 21.82 & 14.65 \\
\hline Blend 6 & 47.20 & 30.27 & 21.97 & 20.61 & 18.80 \\
\hline
\end{tabular}

Table 3. Variation of Nitrogen in $\%$

\begin{tabular}{|l|c|c|c|c|c|}
\hline Days & $\mathbf{0}$ & $\mathbf{1 5}$ & $\mathbf{3 0}$ & $\mathbf{4 5}$ & $\mathbf{6 0}$ \\
\hline Blend 1 & 0.67 & 0.98 & 1.00 & 0.95 & 0.87 \\
\hline Blend 2 & 0.77 & 1.21 & 1.04 & 1.08 & 1.20 \\
\hline Blend 3 & 1.17 & 1.06 & 1.27 & 1.30 & 1.36 \\
\hline Blend 4 & 1.57 & 1.38 & 1.45 & 1.20 & 1.22 \\
\hline Blend 5 & 1.77 & 1.36 & 1.42 & 1.39 & 1.18 \\
\hline Blend 6 & 1.57 & 1.14 & 1.17 & 1.05 & 1.11 \\
\hline
\end{tabular}




\section{Variation of C/NRatio}

Compost maturity index based on $\mathrm{C} / \mathrm{N}$ ratio is a very important parameter for compost production and application. Numerous maturity indices have been proposed, but no single method can be universally applied to all composts due to variation in feed stock and composting technology. $\mathrm{C} / \mathrm{N}$ ratios in the composting bins can also be initially within the range 50:1-100:1 while $\mathrm{C} / \mathrm{N}$ ratios normally encountered in a composting process are around 75:1. (Alex et al, 2008). The compost from the blend 1 reactor would not be suitable for land application since the excess carbon would tend to utilize nitrogen in the soil to build cell protoplasm, consequently resulting in loss of nitrogen in the soil on which it would be applied as in Table 4. On the other hand, the low $\mathrm{C} / \mathrm{N}$ in the compost formed in Blend 6 would not help to improve the soil structure.F

\section{E. Variation of Moisture Content (MC)}

The moisture level required for effective thermocomposting is between $55 \%$ and $65 \%$ whereas kitchen waste usually has higher MC and therefore adding bulking agents such as saw dust, or shredded paper would help to reduce the moisture level and to develop the thermophilic condition. The heat generated during the degrading process also helps in reducing the MC. (Jaya et al, 2006). According to Finstein et al, 1986, moisture loss during the composting process could be used as an index of the decomposition rate, since the heat generation which accompanies decomposition drives vaporization. The $\mathrm{MC}$ in the case of saw dust as bulking agents at the start was $62 . \%$ and during the whole process, it was in the acceptable range of $50 \%$ to $60 \%$. As in figure 3 , the moisture content was adequate and would probably not cause any major differences in process performance

Table.4. Variation of $\mathrm{C} / \mathrm{N}$ ratio

\begin{tabular}{|c|c|c|c|c|c|}
\hline Days & $\mathbf{0}$ & $\mathbf{1 5}$ & $\mathbf{3 0}$ & $\mathbf{4 5}$ & $\mathbf{6 0}$ \\
\hline Blend 1 & 72.11 & 40.51 & 38.32 & 39.94 & 35.56 \\
\hline Blend 2 & 61.70 & 32.55 & 32.79 & 32.69 & 25.25 \\
\hline Blend 3 & 40.73 & 26.53 & 25.59 & 25.08 & 22.04 \\
\hline Blend 4 & 31.12 & 25.75 & 27.62 & 24.92 & 21.05 \\
\hline Blend 5 & 27.17 & 24.41 & 23.43 & 22.89 & 20.19 \\
\hline Blend 6 & 25.05 & 22.19 & 21.43 & 17.32 & 9.18 \\
\hline
\end{tabular}

\section{Variation of Temperature}

Temperature is an important parameter in composting both as a result and as a determining factor for microbial activity. Sanitization of the composting process is achieved by the thermophilic temperatures which kill many of the pathogens that may be initially present in the mixture. (Romeela et al, 2005). Measured temperatures in composting plants usually vary according to aeration mode as well as location of measurement points in the composting mass (Quazi et al, 2000). As in figure 2, the temperature rise gradually due to heat generation from microbial activity and experience an initial rise in temperature followed by declining and stabilized temperatures. The declining phase result as microbial activity decreases due to lower levels of available organic matter (Hagerty etal, 1973).

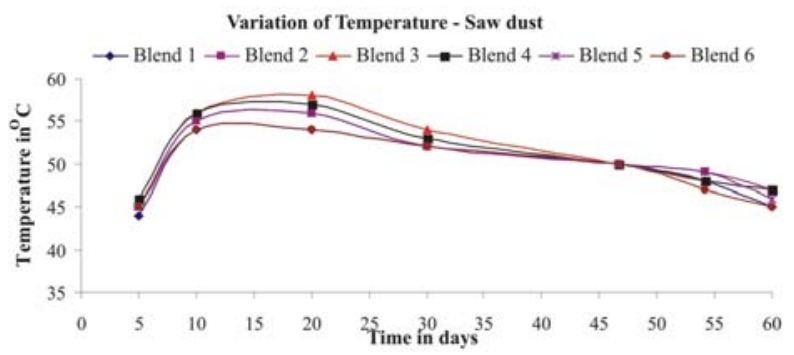

Fig. 2. Variation in days

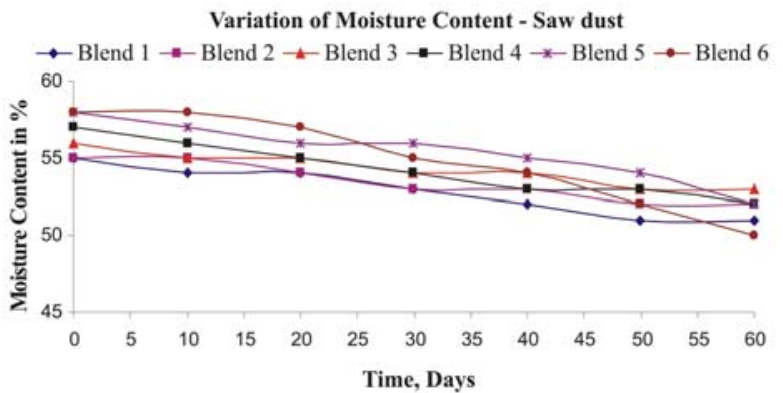

Fig. 3. Variation of Moisture Content

\section{F. Variation of $p H$}

. Variation of $\mathrm{pH}$ is one of the key factors for microbial metabolism. $\mathrm{pH}$ was monitored in the composting substrates every 5 days. In the conditions of excess of nutrients and oxygen, $\mathrm{pH}$ values were expected to drop following aerobic microbial degradation. (Alex et al, 2008), Before treatment, all reactors presented a pH range close to neutrality $(\mathrm{pH} 7.0-7.5)$ and no statistical differences were found between reactors as in Figure4. . Once the treatment started, $\mathrm{pH}$ changes were observed in the reactors. Significant lower $\mathrm{pH}$ values were observed in the reactors with low food waste ratio. $\mathrm{pH}$ values were expected to drop following aerobic microbial degradation. (Alex et al, 2008) 
Before treatment, all reactors presented a $\mathrm{pH}$ range close to neutrality ( $\mathrm{pH} \mathrm{7.0-7.5)} \mathrm{and} \mathrm{no} \mathrm{statistical}$ differences were found between reactors as in figure 4. Once the treatment started, $\mathrm{pH}$ changes were observed in the reactors. Significant lower $\mathrm{pH}$ values were observed in the reactors with low food wasteratio

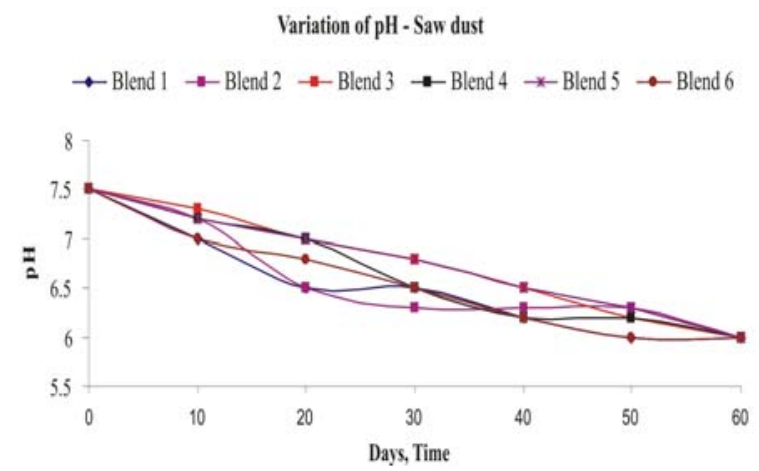

Fig. 4. Variation of $\mathrm{pH}$

G. Bulk density, Water Absorption Capacity and Volume Reduction

Bulk density, porosity, MC and free air space were physical properties of compost materials that play an important role in achieving the optimum efficiency of the composting process. (Romeela et al, 2005). The bulk density of compost is a measure of the mass of material within a given volume. It influenced certain mechanical properties like porosity, strength and compatibility. The dry bulk density for the blend 2 was highest around 330 $\mathrm{kg} / \mathrm{m} 3$ after 60 days of composting because of high rate of decomposition leading to settling. The highest water absorption capacity was obtained with the blend 2 because the increased bulk density as in Table 5 . The volume reduction was also observed in all the bins Table

\section{H. Variation of Total Bacterial Count (TBC)}

During composting, organic compounds were transformed through successive activities of different microbes to more stable and complex organic matter (Garca et al, 1993).The blends were analyzed for TBC during the 60 days composting period at start up, middle and end of the period. as colony forming units pergram (CFU/g)

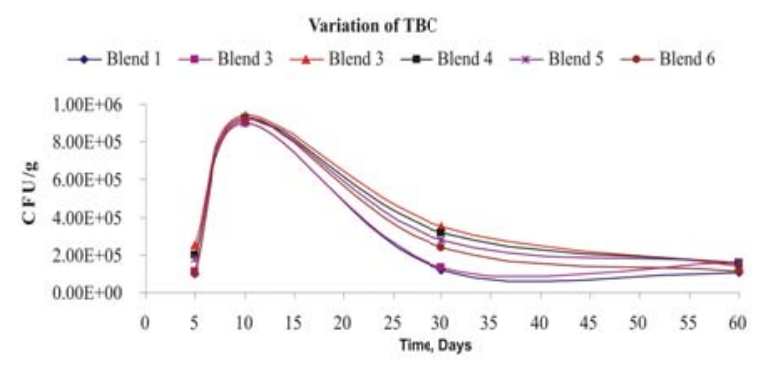

Fig. 5. Variation of TBC

The blends showed similar trendsin increase in quantity followed by decreasing trend indicate that composting materials with higher $\mathrm{C} / \mathrm{N}$ ratios had higher microbial activities than those with lower $\mathrm{C} / \mathrm{N}$ ratios. Microbial activity is at its maximum around ten days since the microorganisms existing in the composting mass have access to the carbon substrates which may act as an energy source for them. As these compounds were degraded, the medium becomes richer in more stable compounds which were less accessible to the microorganisms and so their activity and corresponding respiration also diminish shown in figure 5 .

Table 5. Bulk Density, Wac and Volume Reduction

\begin{tabular}{|c|c|c|c|}
\hline Days & Water Absorption Capacity (\%) & Bulk Density $\mathbf{~ k g} / \mathbf{m}^{3}$ & Volume Reduction (\%) \\
\hline Blend 1 & 27.31 & 295 & 15.38 \\
\hline Blend 2 & 44.52 & 330 & 16.67 \\
\hline Blend 3 & 30.31 & 282 & 16.67 \\
\hline Blend 4 & 44.49 & 295 & 18.18 \\
\hline Blend 5 & 33.22 & 239 & 27.27 \\
\hline Blend 6 & 31.57 & 243 & 40.00 \\
\hline
\end{tabular}




\section{Elemental Analysis}

Compost also contained trace elements essential for plant growth such as copper, zinc, manganese, and iron with nutrients such as potassium and phosphorous. Results as in Table 6 indicated that the compost had a high potential as plant fertilizer with appropriate concentration of nutrients required by the plants (Terman et al, 1973). Other elements in trace forms would also improve the ion exchange capacity of soil. Of all the other parameters, potassium is the only element that is present in a form that can be easily leached. (Polprasert et al, 1996). The low potassium content in the compost (0.05-0.167\%), compared to the recommended $1 \%$ for composts, may be attributed to its draining out in the form of leachate. Effective use of some fibrous material like straw or wood chips can absorb relatively large quantities of water and still maintain their structural integrity and porosity, could prevent the loss of potassium from the compost formed. Phosphorous in organic material was released by mineralization process involving micro organisms. The total phosphorus in the compost of each blends showed gradually lower values loss of total phosphorous was probably due to the mineralization of organic phosphorous and consumption by microbes. Compost application was generally perceived to be beneficial to the soil and crops because of improved soil structure, increased cation exchange and water holding capacity, and the addition of plant nutrients. (Dick et al, 2000, Kernal et al, 2004)

\section{J. Germination Studies}

Finally in the study, the seed germination and root elongation of Lycopersicon esculentum (tomato) species were used to evaluate quality of compost. .After 5 days of incubation in the dark with the procedure in Table 7, the seed germination, root elongation, and germination index (GI), a factor of relative seed germination and relative root elongation) were determined. A 5-mm primary root was used as the operational definition of germination (Tiquia et al, 1996). The percentages of relative seed germination, relative root growth, and GI (figure 6) were calculated (Terman et al, 1973) using equations 1, 2 and 3 and shown in figure 6 .

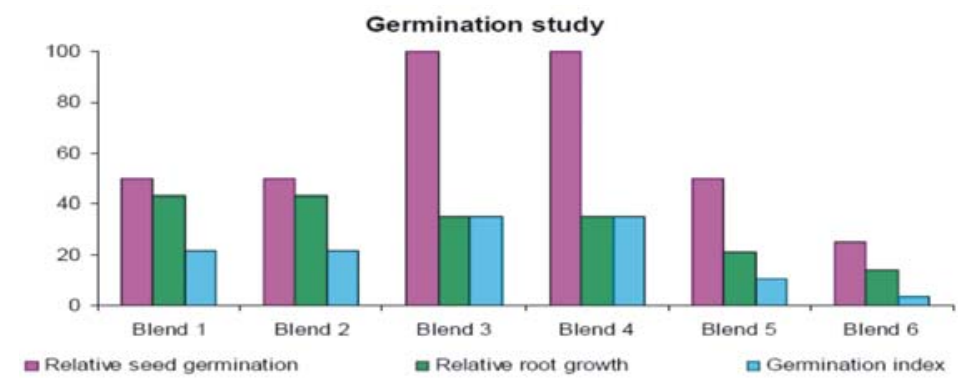

Fig. 6. Germination Studies

Table 6. Percentage of Nutrients and Elements

\begin{tabular}{|c|c|c|c|c|c|c|}
\hline Element & Zinc & Copper & Iron & Manganese & Potassium & Phosphorous \\
\hline Blend 1 & 0.013 & 0.0019 & 0.1065 & 0.0054 & 0.122 & 0.0658 \\
\hline Blend 2 & 0.012 & 0.0017 & 0.1060 & 0.0050 & 0.130 & 0.0660 \\
\hline Blend 3 & 0.010 & 0.0017 & 0.1062 & 0.0054 & 0.106 & 0.0628 \\
\hline Blend 4 & 0.011 & 0.0019 & 0.1065 & 0.0059 & 0.110 & 0.0708 \\
\hline Blend 5 & 0.009 & 0.0017 & 0.1060 & Nil & 0.118 & 0.0608 \\
\hline Blend 6 & 0.010 & 0.0017 & 0.1062 & 0.0050 & 0.114 & 0.080 \\
\hline
\end{tabular}

Table 7. Seed Germination Test Conditions

\begin{tabular}{|l|l|l|}
\hline 1 & Test type & Static \\
\hline 2 & Pre Treatment & Soak in distilled water over night \\
\hline 3 & Temperature & $22 \pm 3^{\circ} \mathrm{C}$ \\
\hline 4 & Light & None \\
\hline 5 & Test Vessel & $10 \times 100 \mathrm{~mm}$ Petri dish Whatman Number 1 paper \\
\hline 6 & Number of seeds & $10-300$ per dish depending on size of the seeds \\
\hline 7 & Replicates & 3 \\
\hline 8 & Test duration & 5 days \\
\hline 9 & End Point & Germination, Primary root $2.5 \mathrm{~mm}$ \\
\hline \hline
\end{tabular}




\section{CONCLUSION}

Performance of In-vessel composting for bio degradable solid waste was evaluated in this study. The results of the investigations enabled one to prove the usefulness of the in- vessel composting method for utilizing bio degradable solid waste. Specific conclusions that can be drawn from this study include the following:

1. The operational indices, moisture content, $\mathrm{pH}$, temperature, and $\mathrm{C} / \mathrm{N}$ ratio were useful in evaluating the composting performance. The levels of indices were relatively stable in the latter part of the composting period and remained constant. The final compost produced in this study was satisfactory for its agricultural application in terms of heavy metal contents.

2. The test of sprouting proved that the mature compost had a better quality than garden soil that was used for comparison. Blends 3 and 4 had a GI of $35 \%$ and root growth of $100 \%$. Germination studies proved to be an ideal for agricultural application.

3. The Blend 4 and 5 had a $\mathrm{C} / \mathrm{N}$ ratio around 20 with physical operational indices within specified range. As bulking agents, saw dust found to offer the best properties, with a high water absorption capacity of over, a neutral $\mathrm{pH}$ and a moderately $\mathrm{C} / \mathrm{N}$ ratio and recycled. Hence blend 4 with a combination satisfactory $\mathrm{GI}$ could be introduced in residential areas and the compost used to fertilize plants.

\section{ACKNOWLEDGEMENT}

The author expresses sincere gratitude to his beloved Chancellor, Dr. Jeppiaar and also heartfelt thanks to his Directors Mr. Marie Johnson and Mrs. Mariazeena Johnson and Dean, Dr. N. Manoharan for providing him the necessary facilities for the completion of this project.

\section{REFERENCES}

[1] Alex Godoy-Fa Undez, Blanca Antizar-Ladislao, Lorenzo Reyes-Bozo and Andres Camano, 2008, Bioremediation of contaminated mixtures of desert mining soil and sawdust with fuel oil by aerated in-vessel composting in the Atacama Region (Chile), Journal of Hazardous Materials 151, pp.649-657.

[2] Antizar-Ladislao. B, Lopez-Real. J and Beck. A, 2004, Bioremediation of PolycyclicAromatic
Hydrocarbon PAH Contaminated Waste using Composting Approaches, 34 (3), pp. 249 289.

[3] Bhattacharyya. P, Chakrabarti. K and Chakraborty. A., ,2005, Microbial Biomass and Enzyme Activities in Submerged Rice Soil amended with Municipal Solid Waste Compost and Decomposed Cow Manure, Chemosphere, 60(3), pp.310-318.

[4] Central Public Health and Environment Engineering Organization (CPHEEO), Government of India,. Manual on Municipal Solid Waste Management, New Delhi, India. 2000.

[5] Chang, J.J. Tsai and K.H. Wu, 2006, Thermophilic composting of food waste, Bio resource. technology. 97, pp.116-122.

[6] Dick W.P, Kerner.H and Hoitink. H.A.J, 2000, Composting and Beneficial Utilization of Composted by- Product Materials, In J.F. Power and W.P. Dick (ed.) Land application of agricultural, industrial, and municipal byproducts. SSSA 14 Book Ser. 6. SSSA, Madison, WI, pp. 315-341.

[7] Finstein, M. S., Miller, F. C.and Strom. P. F 1986, Waste treatment composting as a controlled system. In Biotechnology, a Comprehensive Treatise Microbial Degradation, ed. W. Schienbom. VCH Publication, New York, 8, pp. 363-398.

[8] Garca. C., Hernandez. T and Costa, F, 1993, Evaluation of the Organic Matter Composition of Raw and Composted Municipal Waste, Soil Sci. Plant Nutr. 39, pp. 99-108.

[9] Hagerty. J.D, Pavoni. J.L and Heer. J.E, 1993, Solid Waste Management, Van Nostrand Reinhold Company, New York, USA,

[10] Jaya Nair, Vanja Sekiozoic and Martin Anda, 2006, Effect of pre-composting on vermicomposting of kitchen waste, Bioresource Technology 97, 2091-2095.

[11] Joung-Dae Kim, Joon-Seok Park,, ByungHoon In, Daekeun Kim and Wan Namkoong, 2007, Evaluation of Pilot-Scale In-Vessel Composting for Food Waste Treatment, Journal of Hazardous Materials, $1541-3$, pp. 272-277, 
[12] Kerner. K. Ekinci and D. Akbolat, 2004, Effect of Thermocouple Location on the Optimum Composting Rate, 89(3), pp. 345-353.

[13] Masafumi Tateda, Le Duc Trung, Nguyen Viet Hung Michihiko Ike, and Masanori Fujita, 2002, Comprehensive temperature monitoring in an invessel forced-aeration $\mathrm{J}$ Mater Cycles Waste Management 4:62-69.

[14] Polprasert. C, 1996, Organic Waste Recycling Technology and Management. Wiley, Chichester, West Sussex, England.

[15] Quazi H. Bari, Albert Koenig and Tao Guihe, Kinetic analysis of forced aeration composting -1 . Reaction rates and temperature, 2000, Waste Management and Res, 18: pp. 303-312.

[16] Renkow, A. R. Rubin, 1998, Does municipal solid waste composting make economic sense, Journal of Environmental Management 53, pp. 339-347.

[17] Romeela Mohee, Ackmez Mudhoo, 2005, Analysis of the Physical Properties of an In vessel Composting Matrix, Powder Technology 155, pp. 92-99.

[18] Srinath R. lyengar, and Prashant , P, 2006. Invessel composting of household wastes, Waste Management 26, pp. 1070-1080.
[19] Suzelle Barrington, Denis Choin ere, Maher Trigui and William Knight, 2003, Compost convective airflow under passive aeration, Bioresource Technology 86 pp. 259-266.

[20] Terman G. L, Soileau J. M and Allen. S. E., 1973, Municipal Waste Compost Effects on Crop Yields and Nutrient Content in Greenhouse Pot Experiments Journal of Environ Qual 2, pp. 8489.

[21] Tiquia N. F. Y, Tama. I. J and Hodgkis, 1996, Effects of Composting on Phytotoxicity of Spent Pig-Manure Sawdust Litter, Environmental Pollution, 93(3), pp.249-256.

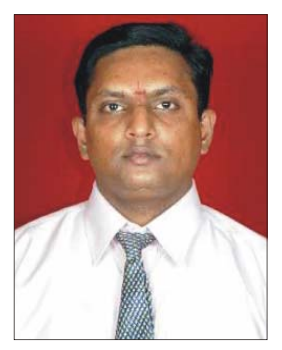

Mr. T. E. Kanchanbhan is a Research Scholar at the Faculty of Civil Engineering, Sathyabama University, Chennai. He has been involved in the preparation of GIS based route network for waste collection for the suburban municipalities in South Chennai $A$ Post-graduate in Environmental Engineering and his field of research is "In-Vessel composting of organic waste with forced aeration". 